\title{
THE INTERTEXT OF HISTORY AND LITERATURE IN FACE OF AN ANGEL, A POSTMODERN/POST-NEOCOLONIAL NOVEL BY DENISE CHÁVEZ
}

\author{
Lana Beth Araujo* \\ Universidade Estadual do Rio de Janeiro \\ Peonia Viana Guedes ${ }^{* *}$ \\ Universidade Estadual do Rio de Janeiro
}

\begin{abstract}
As the title itself suggests, the present article aims at drawing a parallel between history and fiction in the novel Face of an Angel, a first person narrative by Mexican-American writer Denise Chávez. Therefore, it is the focus of the current essay to analyse how the intertextuality between Chávez's plot and the historical periods that work as backdrops to the narrative operate. In order to set the boundaries of this research, three phases were selected for their relevance to the development of the narrator/protagonist, Soveida Dosamantes, and also of the Chicanos' historical process: the period that followed the Mexican-American War, the boiling 1960's and the supposedly promising 1980's. For the purpose of carrying out this paper, works by Stuart Hall, María Antonia Oliver-Rotger, Ellen McCracken, among others, were used as its theoretical support.
\end{abstract}

Keywords: history; fiction; intertextuality; Chicanos.

America! America! God shed His grace on thee, And crown thy good with brotherhood Katherine Lee Bates (our emphasis)

A mighty woman with a torch, whose flame is the imprisoned lightning, and her name Mother of Exiles. [...] [claims].

"Give me your tired, your poor, Your huddled masses yearning to breathe free, [...] Send these, the homeless, tempest-lost to me, I lift my lamp beside the golden door!" Emma Lazarus

Originally a poem, the lyrics of the song "America the Beautiful", written in 1893 by Katherine Lee Bates, describe a country which, besides being inhabited by a virtuous people, will receive from God the blessing of fraternity, as the lyrical-I suggests. The country portrayed in Bates's poem is one that possesses multiple virtues and, by divine power, will promote solidarity and neighborly love. The nationalistic hue Bates's verses are imbued with seems to have found inspiration in Emma Lazarus's “The New Colossus". Written ten years before "America, the beautiful", Lazarus's famous poem describes a nation that was born to receive all unfortunate people who could not find the proper shelter in their own homelands. The lines included in the epigraph are part of the stance engraved on

\footnotetext{
* Lana Beth Ayres Franco de Araujo holds a BA in Português-Literaturas (UFRJ - 1984), a B.A. in Inglês-Literaturas (UERJ 2006) and an M.A in Literaturas de Língua Inglesa (UERJ 2014). Between 1987 and 1988, she was a teacher at Colégio Martins, where she taught Brazilian Literature. Between 1995 and 2003, she was an English teacher at Brasas English Course, giving classes at the three levels - basic, intermediate and advanced. From 2004 and 2006 , she was a proofreader at Editora Rocco, based in Rio de Janeiro. In 2011 and 2012, she translated the first two of volumes of Skeleton Creek, a book series for teenagers by Patrick Carman for Editora Fundamento, based in Curitiba. She has published a number of articles and had the translation of the short story "The Other Family", by Himani Banerji, accepted for publication in Revista Rónai (Universidade Federal de Juiz de Fora). E-mail: araujolana1988@gmail.com

${ }^{* *}$ Peonia Viana Guedes is Full Professor of Literatures in English at the Universidade do Estado do Rio de Janeiro - UERJ. She holds a BA in Português/Inglês from PUC/Rio (1967) and a Ph.D in English from the University of North Carolina at Chapel Hill (1994), USA. She carried out post-doctoral studies in Post-Colonial Literature at UFMG (2003-2004). She teaches and develops research related to the representation of the female subject in contemporary literature, with focus on identity, gender and ethnic issues. In her studies, Peonia Viana Guedes uses the principles of feminist, post-modern and post-colonial theories and criticism. She has published Em busca da identidade feminina: os romances de Margaret Drabble (1997), as well as numerous articles and book chapters. E-mail: peoniaguedes@ terra.com.br
} 
a plaque attached under the Statue of Liberty, the epitome of the libertarian and also welcoming spirit the U.S. embodies. Would this feeling be really encouraged among all American citizens? Would any individual born on U.S. soil or drawn to it in search of its "generosity" be included in this brotherhood? Would "Mother America" grant all "her" children that benevolence, without discriminating against them by ethnical heritage, social condition or gender?

Historical facts, whether they be officially documented as such or reconstructed in literary works, have proved that "Mother America" has not been so unconditionally welcoming. It is just this filial distinction that Mexican-American writer Denise Chávez ${ }^{1}$ represents in her novel Face of an Angel. In her narrative, the narrator/protagonist Soveida Dosamantes makes use of self-referential discourse to recall the trajectory of some of her family members. Despite directing the focus of her account on women, Soveida includes the men who took part in her life experience and who, some way or other, played a relevant role in her development process. Chávez then conceives a fictional autobiography, in order to give voice to a woman character who, like herself, is American by birth, but labeled by her Mexican heritage. Denise Chávez establishes a dialog between history and literature, sprinkling in historical references throughout Soveida Dosamantes's life writing, and it is this intermingling of history and fiction in Face of an Angel that this article intends to discuss. Three historical phases that serve as the backcloth to passages meaningful in Soveida Dosamantes's narrative have been selected: the aftermath of the American Civil War-her genesis in her hometown Agua Oscura; the effervescent 1960's, marked by the ideological conflict of the Cold War; and, finally, the 1980's, which were expected to be the "decade for the Hispanics".

In Face of an Angel, the historical process involving Chicanos in the US intermixes with fiction to form the ethos the readers are provided with. Canadian scholar Linda Hutcheon opens her essay "Historiographic Metafiction-Parody and the Intertextuality of History" by quoting two important French thinkers, Michel de Montaigne and Michel Foucault, who, although set apart by a chronological gap of four centuries, share the same view towards the dichotomy of fiction and history. By quoting Foucault, Hutcheon ratifies that a fictional work cannot be conceived in isolation, since "[...] a book [...] is [always] caught up in a system of references to other books, other texts, other sentences: it is a node within a network" (Foucault qtd. in Hutcheon 3). Borrowing the words employed by the French philosopher, it seems legitimate to state that Face of an Angel is a node within Chicano cultural/ literary/historical network, since it is not isolated from the historical process that has brought it into being. Thus, as Chávez locates her novel within the Chicano historical context promoting a dialog between history and fiction, it seems appropriate to affirm that Face of an Angel fits Linda Hutcheon's concept of historiographic metafiction, as the following quotation attests to:

\begin{abstract}
The postmodern relationship between fiction and history is [a] [...] complex [...] interaction and [has a] mutual implication. Historiographic metafiction [...] situate[s] itself within historical discourse without surrendering its autonomy as fiction. And it is a kind of seriously ironic parody that effects both aims: the intertexts of history and fiction take on parallel [...] status in the parodic reworking of the textual past of both the "world" and literature (Hutcheon 4 - our emphasis).
\end{abstract}

Considering the interaction between fiction and history as a defining characteristic of postmodernism, it seems correct to attribute to Chávez's novel such a classification. As Hutcheon affirms, postmodernism is "a poetics or an ideology [...] [that] clearly attempts to combat [...] [the] modernism's hermetic, elitist isolationism that separated art from the 'world', literature from history" (Hutcheon 28). It is exactly this blurred boundary between art and historical research, this "intertext of history and fiction" that is detected in Face of an Angel. Although Chávez did not mean to discuss history in her literary work, historical events give her fictional narrative a contextual flavor and work as a situational marker which guides the readers through the novel's chronological development. In addition, the Chicano 
universe composed by fictional and real elements is not described by someone belonging to a privileged social class, respectful enough to have the authority to tell his/her story. Rather, Face of an Angel's narrator is a humble waitress, from a small town in New Mexico, who decides to share with her readers her private universe, chronicling it in a humorously critical way. This individual account of history is conceptualized by British professor and theorist Susannah Radstone (2000) in reference to autobiography, but which is applicable to the self-referential discourse Chávez engenders for her narrator/protagonist:

Histories of autobiography locate individual autobiographies within historical epochs and their aesthetic, formal and thematic concernsconcerns which are inextricably tied to the historicisation of the ontology of the subject [and] [t]his is [...] the case [...] of marginal autobiographies-women's, working-class or ethnic autobiography, for instance. (Radstone 203-204)

Still discussing the limits between fiction and history, Hutcheon helps clarify the issue. In A Poetics of Postmodernism (1988), Hutcheon discusses the Hungarian thinker Georg Lukács's concept of historical novel. As Hutcheon points out, Lukács sees the fictionalization of history as the construction of a microcosm, the representation of a macro panorama that generalizes (as it consists of a recreation of types and life scenes) and yet concentrates (since it squeezes that general panorama within a fictional realm) the reality it refers to. In Face of an Angel, this microcosm is Agua Oscura, the narrator/protagonist's hometown, a fictional space which generalizes the Chicano universe that holds inside it (stereo) types. This microcosm is built by Chávez who endows her narrator/protagonist with the authority to describe it. The character's main mission is, thus, to provide the readers with a portrait of a minority group outlined on a diachronic axis. Soveida Dosamantes makes use of her narrative to offer an alternative reading of the Chicano universe unlike that biasedly conceived by the white US establishment. Therefore, Chávez's novel seems to fit Lúkacs definition of historical novel as a cut-out of reality, since it embodies the representation of a larger picture.

The role of literature as a tool for minorities to subvert the historical mainstream discourse is addressed by Finnish professor Kuisma Korhonen (2006), who concludes that, by using literary creativity, minorities could provide another version of historical facts unlike the fossilized one granted by the official historical discourse:

\begin{abstract}
[A]rtistic imagination is an essential supplement to historical discourse when the intention is to give voice to those who are marginalized from the centralized production of knowledge [...]. Literature is not only nostalgic entertainment, but serious research on world-making language, and their multifaceted relationship. (Korhonen 18-19)
\end{abstract}

Korhonen deconstructs the myth that literature, as an artistic manifestation, should be opposed to the rationality and impartiality of the historical discourse blessed by academic authority. As Korhonen argues, literature, in spite of its purpose of entertaining, develops its body of writing based on research about the so-called reality. Korhonen's position appears to find support in US historian Hayden White's essay "Historical Discourse and Literary Writing", included in the collection of critical articles edited by Korhonen himself. White attributes to literature the badge of "history's other" and argues that literature, besides having found out a dimension of reality that history has never acknowledged, had built up "techniques of writing that undermined the authority of history's favored realistic or plain style of writing" (White qtd. in Korhonen 25). White exposes "the other side of the coin" by discussing the interfacial relationship between literature and history by exposing the mainstream differentiation of both fields of study:

History is one of the "others" of literature inasmuch as literature is understood to be identifiable with fiction. Because history wishes to make true statements about the real world, not an imaginary or illusory world. Secondly, history is literature's other inasmuch as 
literature is understood to be identifiable with figuration, figurative language, and metaphor, rather than with literal speech, unambiguous assertion. (White qtd. in Korhonen 25).

This interaction between history and literature spotted by White is grounded on two levels. The first refers to the content both areas intend to develop: the "tangible" reality. The second, in turn, is related to the way this "palpable" world is textually dealt with: while the historical discourse is descriptive and analytical, literature recreates it by means of linguistic devices. In sum, if history describes and analyses events which are determinative for the development of society, literature relies on imagination to reproduce the same world history objectively depicts.

Martinican historian Edouard Glissant (1992) also aligns literature with history, regarding them as sorts of narratives that have the "world" as their work field. If history utilizes an authoritative discourse literature, as its counterpart, assumes the task of defying it. Glissant establishes a binomial relationship between the historical research and discourse and its artistic equivalent, which is the reconstruction of reality carried out by literature. The interlink between both discourses is characterised by complexity and ongoing transformation, given the many sides it assumes both synchronically and diachronically. Glissant then states that:

$[\mathrm{H}]$ istory $[\ldots]$ is the "reflection" of a collective consciousness today $[\ldots]$ concerned with the obscure areas of lived reality [...]. History [...] and Literature form part of the same problematics: the account, or the frame of reference, of the collective relationships of men with their environment, in a space that keeps changing and in a time that constantly is being altered. (Glissant 69-70)

As the focus of this paper is a novel whose plot is intended to recreate Chicano society, it is not possible to disregard its Mexican roots, and, much less, to think of Mexican history without discussing its past as a Spanish colony and its present economic and political dependence on the United States. Considering Mexico's relations with Spain and the US, we can conclude that, from the sixteenth century onwards, the reign previously run by Montezuma II started a long, gradual and continuous process which led it to a gradual loss of its national and cultural identity. Since 1521, when Spain conquered the former Aztec empire, it started suffering the most emblematic effects of colonialism: the exploitation of its natural resources and the process of acculturation. In the name of imposing what was thought to be "civilization", the Spanish crown both depleted the empire's gold and silver and tried to erase its indigenous past. The traces left by the Aztecan culture were swept away for the sake of "taming" a "savage" people to give way to "civilization". Therefore, from 1521 onwards, the indigenous people were blended with their colonizer, gradually losing their ethnic identity.

This loss of racial/ethnic/cultural characteristics did not have as its cause only the Spanish conquest of Mexican lands and civilization. In the mid-1840's, with the invasion of Texas by the U.S., Mexico underwent a "new" colonization process; that is, two hundred years after the Spanish domination, it was again subjected to an economically powerful nation. This time, however, the historical moment was another one: by the nineteenth century, thanks to "an early start in mechanization production [...], [it was possible for the U.S. to accumulate] capital and [dominate] New World markets" (Acuña 2). It was then easier for the U.S. to advance over Mexican territory and start a neocolonial relation with another former colony which had gone through the usual exploitative colonial process. These two phases of economic domination affected Mexico both in terms of finances and national self-esteem, causing Mexican people to see themselves as inferior. It is in this scenario of economic, social and cultural limbo that Soveida Dosamantes builds her first-person narration and shares particularities of the Chicano culture. Subjected to a past of oppression, Mexicans and Mexican-Americans learned that mestizaje was a drawback. Over centuries, they learned that, due to their dark skin, their "unrefined" culture and, consequently, their "short cognitive reach", they needed the tutelage of the "more intellectually privileged" Anglos, whose "superiority" was legitimated by their white European background. 
Postcolonial studies, however, question the superiority of white Europeans and stress the pride that should be felt by multiracial people. It is interesting to observe what Denise Chávez herself said in this respect during an interview to U.S. journalists Debbie Blake, Doug Anderson and Rosalva Ray:

We have to remember where our roots are. Remember that the Chicanos are this mestizaje. We are a mixture of several worlds; a mixture bubbling up to form some kind of new nourishment. We are new beings that come out of all those old ways of being and existing. We are the new stock from the old soup (Denise Chávez during an interview to Debbie Blake, Doug Anderson and Rosalva Ray-our emphasis).

Note that Denise Chávez defines Chicanos as "the new stock from the old soup", reminding us of what "Arabian-Jewish"-as she defines herself-theorist Ella Shohat (2008) says about the terms "hibridity" and "syncretism". In an attempt to problematize miscegenation in postcolonial subjects and cultures, Shohat mentions the concept of cultural anthropophagy proposed by Brazilian modernism and tropicalism:

The culturally syncretic protagonists of the Brazilian modernists of the nineteen twenties [...] might be seen as "postcolonial hybrids" [...]. Brazilian modernists, and [...] the Tropicalist movement of the late nineteen sixties and early nineteen seventies, simply assumed the New Worlders were culturally mixed, a contentious amalgam of indigenous, African, European, Asian, and Arab identities (Shohat 109).

Both Chávez and Shohat interpret the postcolonial ambience as a "contentious amalgam", that is, an indistinct mixture whose components are in permanent state of confrontation and/or transformation. The individuals involved in this clash, however, do not fight in equal conditions. Those who have always enjoyed a privileged social position and believe in their "racial purity" cannot accept others identified as of different ethnical heritages. What lies underneath all that is the concept of cultural identity developed along with the advent of national states in the seventeenth century and the political and economic power they exerted on their colonies.

Although the current article does not intend to discuss in depth the historical panorama of each of the three stages focused on, it indeed aims to see how history is interwoven with fiction, functioning as a factual reference to Chávez's narrative. Although other historical periods could have been chosen, regarding Chicanos' historical process, the late nineteenth century, the 1960's and the 1980's seem to have been crucial for the development of Chávez's narrative. Therefore, we will discuss the historical conditions that concurred to the Dosamantes' origin (late nineteenth century), the hustling 1960's, when the first seed of ethnic awareness was sown in the narrator/protagonist's mind, and the 1980's, when she, mature enough to do so, decides to cultivate that very seed.

\section{Manuel Dosamantes's trajectory: from dominated old Mexico to appropriated New Mexico}

In the very beginning of Face of an Angel, the reader is introduced to Soveida Dosamantes's genealogical tree, which clearly shows that, besides aiming to develop a chronologically organized account, she means to establish a cause-consequence relation between past and present. As U.S. professor Francine Richter states, "[m]uch of what makes up Soveida's present, everyday existence has its origins over the border in Old Mexico" (Richter 277). Therefore, it seems appropriate to examine the historical and political panorama that pushed Manuel Dosamantes, the narrator/protagonist's great-grandfather, out of Mexico and towards the border between Mexico and the United States.

The first waves of American merchants arrived in the current U.S. state of New Mexico around 1820, and, during the following two decades or so, they paved the way for the invasion that took place during the 1840's. With a predominantly agricultural economy, New Mexico was dominated by American landowners who expelled local poor peasants and sheep raisers, establishing then a monopoly in agriculture and cattle 
raising. According to Soveida's narrative, her greatgrandfather Manuel arrived in New Mexico around 1875 , when " $t$ t]he railways ushered in the industrial period, accelerating the decline of ruralism and the expansion of capital-intensive industries"(Acuña 78). However, the fictional small town of Agua Oscura created by Denise Chávez apparently was not much affected by that urge of development, as it remained rural until the narrator/protagonist's moment of enunciation.

In the second chapter of the novel, entitled "The Sleepwalker", Soveida narrates her great-grandfather's trajectory and how her family started. Born in Guanajuato, a "colonial town", as Soveida herself defines it, Manuel Dosamantes had chosen California as his destination. Nevertheless, for reasons not informed in the novel, "he never made it" (Chávez 5). He then leaves his hometown, crosses the Mexican city of Nuevo Laredo and finally reaches Fort Davis, in the US state of Texas, where he worked for a while. Afraid of being forced to marry the daughter to a farmer he had worked for, Manuel Dosamantes faced heat and the desert, escaping from a fate he refused to accept. Nonetheless, tired of running, he ended up settling down in the (fictional) town of Agua Oscura, New Mexico. While chronicling her great-grandfather's escape, Soveida describes Manuel and his original family, portraying a scene of material need:

[T] he picture of his mother [...] [,] his father[,] his brothers[,] and himself, as a boy, standing next to a dried tree, in a nowhere land on the outskirts of his colonial hometown, Guanajuato $[; \mathrm{h}] \mathrm{e}$ had lived in poverty and hope there, full of parched dreams from all the heat" (7-my emphasis).

While describing the picture, Soveida alludes to Manuel's "parched dreams from all the heat", demonstrating that he, from early age, thirstily dreamed of leaving that place whose inhospitable weather prevented him and his family from having a better life. The implacable climate, however, was not the only cause for the Dosamantes family's economically unfavorable conditions. That "heat"-maybe also a metaphor for an infernal environment which lacked all sorts of comforts-is the consequence of centuries of political and economic control both by Spain (colonial period) and by the States (annexation of Mexico). In short, the Mexico Manuel Dosamantes was born and grew up in was what remained from a country once more marked by political and economic dominance: with the Treaty of Guadalupe Hidalgo signed in 1848, following the socalled Mexican-American War, Mexico had officially confirmed its condition of a still dominated country, since over half of its territory had been annexed by the United States. The poor rural environment shown in the picture of her great-grandfather and his family was, thus, the result of what Rodolfo Acuña (1988) clearly explains in the quotation below:

\begin{abstract}
Mexico's resources [...] had been plundered and its lands monopolized by a few latifundistas and the Catholic Church. The lack of political stability and poor transportation retarded the modernization of agriculture and the development of national markets. (Acuña 2)
\end{abstract}

The scenario of poverty that marked Manuel Dosamantes's memories from Mexico pushed him out of his homeland and made him head for "the land of opportunities". Having the already prosperous California as his planned destination, Manuel Dosamantes, after a period in Texas, ends up in a small town maybe as small as his own, Guanajuato. It is noteworthy Manuel's cyclic fate: in spite of making all the effort to move to a more cosmopolitan place, he wound up in a tiny provincial village. Note what the narrator/protagonist says about the relationship between her ancestor and her birthplace:

[Agua Oscura's] severity suited him. $\mathrm{He}$ responded to this land as a hearty hungry woman does to lovemaking. He found it gave him what he needed: a response. He was able to see the change, dramatically. Water was this land's lover, and this love affair, the push and pull of nature with man, a man with his spirit, was what drew him to Agua Oscura. It allowed him to feel, at last, at home. (7) 
As Soveida herself concludes, there was a strong link between her great-grandfather and Agua Oscura. Maybe it was the similarity between the fictional tiny rural town in New Mexico and the real Mexican city of Guanajuato that held Manuel Dosamantes on to the former. The dramatic change Manuel saw might have taken place inside himself, since the Manuel who arrived in Agua Oscura was not the same who left Guanajuato. It was then a paradoxical feeling that Soveida's ancestor might have developed: the heat that pushed him out of Guanajuato was exactly what made him feel at home in Agua Oscura. However, the experience he acquired throughout those years of hard work on so many farms enabled him to change it and strengthen that love affair between water and the village. This way, he would be taming the intense heat-may it be interpreted denotatively or connotatively-which drove him out of Mexico and yet rooted him in the Mexican-American town of Agua Oscura. The harmonic relation between Manuel Dosamantes and his new "homeland" may be read as the crowning achievement of a hard working man who, despite all odds, succeeded in acquiring all that nature and history had denied him.

In the same chapter, Chávez again uses history in the narrative, creating a counterpoint to Manuel Dosamantes's story: the origin of the narrator/ protagonist's great-grandmother. Considering Chávez's intention of portraying a place characterised by miscegenation, she purposely creates a character like Elena Harrell. The combination of a Latino Christian name and a British family name promptly suggests a mix-raced persona. Born in Chihuahua, where "North American merchants made fortunes from" (Acuña 54), Elena Harrell could not have had a more noble background: she was the daughter to "Bartel Harrell [,] a miner and speculator [and] Estrella de las Casas, from $[\ldots]$ one of the wealthiest families in the state of Chihuahua" (9, our emphasis). The narrator/protagonist then defines her most ancient ancestor as a miner and a speculator, that is, an Anglo who was drawn to Mexico both to exploit its natural resources and to speculate. ${ }^{3}$ Thus, according to Soveida, Bartel Harrell was an Anglo and a financial adventurer who came to Mexico in order to get rich over extracting its natural resources (miner) and grabbing and selling its lands (speculator). Considering both Harrell's activities, it seems accurate to conclude that he truly embodies the Anglo (neo) colonizer, as he is engaged with exploitative actions which are emblematic of the neocolonial era.

Bartel Harrell's arrival in Mexico finds explanation in two important historical pieces of information: the Monroe doctrine, introduced in 1823, and the Manifest Destiny, ${ }^{4}$ a belief developed twenty years later. According to the political and economic creed, the United States was endowed with enough power to take economic and political control over the northern hemisphere, attempting to "protect" it from European domination. Two decades after the signature of the Monroe doctrine, the ideology of Manifest Destiny legitimated President James Monroe's policy, as professor María Antonia Oliver-Rotger explains: “[t] he ideology of Manifest Destiny was instrumental for speculators, land-developers, and large companies that rapidly moved into the Southwest" (Oliver-Rotger 99). In conceiving Elena Harrel's origin, Chávez seems to have resorted to history, as Oliver-Rotger informs: “[s] ome of the wealthy sectors of Mexican society struggled to remain in control of their properties and established alliances with "Anglos by means of marriage or business ties” (Oliver-Rotger 100-our emphasis).

The historical panorama marked by cultural/ ethnic blending and discrimination on the one hand and by economic/political control on the other affected the narrator/protagonist's sense of "nation". By joining in marriage a Mexican farm worker and an aristocrat of British and Spanish background, the author designs a fictional family stream, attempting to evidence the blending of races and walks of life that many real Mexican-American families consist of. By doing so, Chávez attributes to Manuel Dosamantes and Elena Harrell the role of the primeval cells of Soveida's family as far as her genealogical tree traces back. In Soveida Dosamantes's "private nation", which is her domestic and familial ambience, Manuel and Elena function as her ancestral milestones, as they are the very starting point of her familial lineage. Considering that family is the first sample of social organization any human being experiences, where people acquire the most relevant 
aspects of a nation/culture which are language and customs, it seems advisable to examine the concept of national culture developed by Jamaican theorist Stuart Hall (2007). It would be, thus, interesting to see how the notion theorized by Hall manifests in a fictional character who grew up in an environment historically characterized by political/economic domination and ethnic/cultural blending.

While discussing aspects that the concept of "national culture" involves, Hall identifies five main elements. One of them, which he labels as the "foundational myths", seems to suit Manuel Dosamantes and Elena Harrell, the characters now in question. Although Hall develops this notion in relation to the binomial nation/nationalism, it seems perfectly applicable to Chávez's Face of an Angel, since the idea of nation, in postcolonial writing, does not have the macro dimension most people commonly share. In a world where cultures merge all the time, it is getting harder and harder to establish the boundaries between them. This way, what could be regarded as regional might be seen as universal and vice-versa. Apparently, Soveida Dosamantes senses it in the first chapter of "The Book of Service", the manual she wrote to her substitute at El Farol, the Mexican food restaurant she worked at all her life. Chávez's narrator/protagonist then theorizes: "when you grow up in the Southwest, your state is your country. There exists no other country outside that which you know. Likewise, neighborhood is a country. As your family is a country. As your house is a country. As you are a country" (171). Soveida then shows that she is aware that there is no universal notion of country. For her, the idea of country is a concept developed within each individual, eliminating any possibility of a general definition accepted worldwide. Miscegenation in the Dosamantes family started so long before the moment of enunciation that Soveida loses track of its ethnic components. Besides, until Soveida acquires scholarly knowledge on her own ethos, she is completely unaware of the reflexes of racial blending and the economic subjugation on her community. Thus, Soveida's greatgrandparents can be seen as the foundational myths of her "private country", the country that she knows, as she herself argues. To Soveida Dosamantes, country is a concept that covers a narrow range, "[an] imagined community [...] [that] is [...] conceived as a deep, horizontal comradeship" (Anderson 8). Soveida's idea of country also seems to find theoretical support in the book by Oliver-Rotger (2003). The narrowed view of what a country could mean may be a consequence of the exclusion of non-WASP's from the US society, as Oliver-Rotger argues:

Since American society is not an open ethos where one may participate independently of race and class, but a "private" space where citizenship is restricted, it is in these very "ragged edges" of society that resistance struggles to the present configuration of a "privatized" public sphere emerge. (OliverRotger, 131)

Nevertheless, it is important to point out that it was Soveida's cultural awareness and literacy that enabled her, at the moment of enunciation, to theorize this individuality. As a theoretical support of this privateness, Hall quotes American sociologist Immanuel Wallerstein:

[T] he nationalisms of the modern world are the ambiguous expression [of a desire] for $[\ldots]$ assimilation into universal [...] and simultaneously for $[\ldots]$ adhering to the particular, the reinventation of differences. Indeed it is a universalism through particularism and particularism through universalism". (Wallerstein qtd. in Hall 615)

It is important to note that Denise Chávez made her narrator/protagonist find her first origin in the junction of a Mexican poor rural family and an AngloHispanic rich lineage. The Dosamantes' miscegenation then goes beyond race and ethnicity: it also includes place in the social pyramid. The weaver of the first -person discourse in Face of an Angel portrays herself as a mestiza, a "halfbreed", for having descended from such a mixed origin. This mix, considering social and ethnic aspects, seems to have accounted for, or at least contributed to, the complex family relations she relates. In a very indirect and pulverized way, Soveida 
Dosamantes identifies in her great-grandparents' story the explanation for her Chicana experience.

\section{Soveida Dosamantes's Chicana awareness: the cultural and political effervescence of the 1960's}

"The One", the nineteenth chapter of Face of an Angel, is particularly meaningful in reference to the historical contextualization of the novel. This passage narrates a talk between Soveida and her first husband, Ivan Torres, during which she hears for the first time the term "Chicano". It is when Soveida Dosamantes takes notice of the relation between herself as an individual and the concept conveyed by that word which, at first, sounded so strange.

As Rodolfo Acuña states, “the 1960's were a time of discovery, a decade when presidential candidates and the media suddenly discovered that poor people lived in 'America"' (Acuña 307). So, the social condition of minorities-and Mexicans were included in the group-gained importance in the US political scenario during the effervescent sixties, a time of social political awareness and upheaval guided by a strong sense of humanism. In the wake of the civil rights movement, which peaked in the early 1960s, a concern for human beings' welfare marked the decade. In this respect, US professor Ellen McCracken remarks that:

the sociopolitical space of the 1960 s and 1970s in which blacks, students and antiwar groups agitated militantly for social change, Chicanos sought the political rights and cultural recognition that eluded them under the traditional model of the US "melting pot". (McCracken 3)

Although Mexican-Americans' hopes (and claims) for social changes remained restricted within political speeches, academic studies and press articles, without any effective improvement in their life style, Chicanos' political struggle in the decade left a positive legacy. In fighting for having their rights legally recognized and respected, Chicanos forced the US mainstream to review its concepts and change its historical discourse. In this respect, Oliver-Rotger comments: [t]here is no doubt that one of the legacies of the political struggle of Chicanos in the 60's is [...] the concern for the revision of American history in relation to the history of others[;] [h] owever, before such a revision, a positive sense of community had to be forged [...]. (OliverRotger 96)

During the 1960's, the American economy suffered a severe setback, since its products were losing market to those made in Germany and Japan. While the U.S. industry was "pay[ing] high dividends and extravagant executive salaries" (Acuña 307), its German and Japanese competitors were succeeding in launching better and cheaper goods. In order to become more competitive, the U.S. industry decided to destine financial resources to technology and machinery, forcing it to demand a more qualified labor that could deal with the new equipment and updated technical knowledge it invested in. This turning point in the US industry excluded Chicanos from its plants' workforce, deepening the gap there had always been between Mexicans ${ }^{5}$ and Americans, as the former, in terms of education, rarely went beyond the eighth grade. Once marginalised in the labor market, Mexican men gave way to their female counterparts and, from the 1960's on, the entrance of Mexican women in the industrial workforce was massive. Nevertheless, women's ingress in the labor market was not restricted to the plants. In the faraway fictional town of Agua Oscura, the young Soveida Dosamantes, at eighteen years of age, began her career as a waitress at El Farol.

The unfavorable social condition Mexicans and Mexican-Americans were confined to was not restricted to the urban environment. If, on the one hand, the Chicanos employed by the industrial sector were affected by the demand for qualified labor, on the other, the Chicanos who lived in the fields suffered from the exploitation of labor. In Chávez's novel, Ivan Torres tells Soveida Dosamantes that "the campesinos were breaking their backs in [their] lettuce fields [and their] families [were] torn apart by the great farm machine, and children hurt and damaged by pesticides" (130). As Ivan points out, the industrialisation of agriculture, which had been destroying the subsistence agricultural production since late nineteenth century, was now 
subjecting peasants to a practically slave labor, not to mention the toxic effects chemical products had on the workers' families, including the children.

What is noteworthy is that the plight of campesinos is not revealed to Soveida by a union leader or a political scientist. When the narrator/protagonist defines Ivan Torres as a guy "who [had] lived in California and the only man in Agua Oscura who [did not] wear socks with shoes" (128), she portrays him as a modern outsider if compared to their hometown's young male provincial inhabitants. "The One" referred to in the chapter title is "the one" from whom she hears the term "Chicano" for the first time; "the one" who informs her there is a political struggle involving peasants of Mexican background-like them-somewhere in the States, outside their Mexican-American small world. As Soveida's narrative suggests, Ivan Torres belongs to a southwestern middle-class family and went to California to acquire a better education. From 1967 on, bigger and bigger waves of Mexican students headed for California where they got in touch with other groups engaged in the civil rights movement. For cultural reasons, as Acuña argues, "[m] ost Chicano students clearly identified with the United Farm Workers: its successes and tribulations became their own" (Acuña 335). Intentionally, as it seems, Denise Chávez created a Mexican-American character, who, after a long stay in California, came back to his tiny southwestern village to trigger the narrator/protagonist's cultural awareness process by talking about Cesar Chavez and the campesinos' strife for better salaries and labor conditions.

In Face of an Angel, the transformative 1960s were represented not only in Ivan Torres's political pamphleteering discourse in the nineteenth chapter of the novel. Two chapters earlier, humorously entitled "El Jester" in a reference to Soveida's first boyfriend, the reader is brought into that decade in a comic episode involving the two characters. Jester and Soveida go to the local drive-in to see Doctor Zhivago, a 1965 Academy Award winner film. During the movie session, the narrator/protagonist has her first-and disastroussexual experience. Acknowledging a similarity between herself and Lara, the movie's protagonist, Soveida, as a narrator, draws a parallel between the two at the moment of enunciation. Again, Chávez promotes a dialog between her narrative and other sorts of artistic languages, in this particular case a movie, which, in its turn, is based on a literary work. As the quotation below illustrates, Soveida compares the moment of affliction she underwent with Jester to the situation the protagonist in the movie was going through:

\begin{abstract}
There was nothing exciting or sexy about the way Jester treated me, nothing personal or even real. I watched myself dissociated from my feelings, as the poor unwitting Lara had. Trapped by an older, selfish lover, she hardly recognized her own haunted face in a shadowy mirror. (119)
\end{abstract}

While engendering a postmodern historiographic metafiction, Chávez brings into her fictional ambience David Lean's cinematographic version of Russian novelist Boris Paternak's 1957 novel Doctor Zhivago, which has the Russian Revolution as its backdrop. According to the critical comment found on the website Goodreads, Pasternak's novel is defined as "[an] epic tale about the effects of the Russian Revolution and its aftermath on a bourgeois family". ${ }^{6}$ For criticizing the Soviet regimen, Pasternak's novel was quite welcomed in the West and quickly became a best-seller; Pasternak was awarded the 1958 Nobel Prize of Literature. The scene described in the chapter now in focus recreates in the novel-even in a very indirect way-the Cold War environment, when any anti-Soviet posture-whether it was a political speech, a military action or even a fictional work that could possibly defend western values-was gladly welcomed. Chávez's alluding to the famous production by the British filmmaker involves more than a historical reference. In projecting Doctor Zhivago on the screen of that drive-in in Agua Oscura, the author used maybe 1965's greatest blockbuster as a spice to her narrator/protagonist's account.

If in the second chapter of Face of an Angel, Denise Chávez resorts to history to lead her readers back to Soveida Dosamantes' origin, in the nineteenth chapter, Chávez adds to the novel a 1960's flavor. While mentioning Cesar Chaves and the campesinos' 
situation back then, she not only contextualizes the novel's phase in question but also tells (or reminds of) her readers about an important passage in Chicanos' recent historical process. This contextualization is not limited to a mere reference to the Chicano political leader and to the abominable situation rural workers were then passing through. The fact that Denise Chávez engendered a character like Ivan Torres, a 1960's typical Chicano middle-class young man, who had recently arrived from California, to be the spokesperson of such a period completes the ebullient atmosphere that functions as the setting for the chapter. In addition to references to the campesinos' political movement, which was factual, Chávez again makes use of intertextuality by establishing an interconnection between her narrator/ protagonist's account and the filmic version of a novel labeled as an artistic emblem of the decade.

\section{The 1980's: the decade for hispanics?}

When, in the early 1980's, Raúl Izaguirre7 said "I firmly believe that the immediate future will be our 'Golden Age", it was certain that Hispanics, whatever their origin could be, would find in that decade the proper time to grow in the States. The manifest enthusiasm in Izaguirre's statement probably meant a sort of reaction against the disappointment caused by the economically and socially sterile 1970 's. About this hopeful expectation Ellen McCracken (1999) also signals that:

[i]ndeed, the media and political commentators heralded the 1980s as "the decade of the Hispanic", a moment of history in which this rapidly growing minority group would receive its long overdue rights and recognition. (McCracken 3)

Contrary to all expectations, the project of recognition, respect and, thus, advancement for the minorities did not become reality. In fact, the shift from the 1960's to the 1970's "changed rapidly [...] from one of intolerance of the establishment to a severe backlash against the poor and the minorities" (Acuña 401). Once more, the encouraging foresight for the 1980s proved to be another letdown. The "Rambo years", as Rodolfo Acuña named the period in a reference to Sylvester Stallone's warlike character, were definitely not the time for Hispanics to be positively noted and acknowledged, evidencing that " $[\mathrm{h}]$ istory has since proven Izaguirre wrong" (Acuña 413).

As observed along the world's historical process as a whole, it is almost natural that, after a period of political, economic and social retrocession, a wave of hopeful mood develops expecting that better times must come over. This "ideological seesaw" might explain Izaguirre's encouraging position towards the 1980's, which were then just beginning. Historically speaking, it was during the 1980's that Hispanics started figuring within the US public administration as representatives of their community, as informs Acuña: "Chicanos began moving into government positions that dealt with the implementation of policy" (Acuña 415). During the Reagan administration, names such as Nestor D. Sánchez, Cathis Villapondo and Vilma Martínez were appointed as heads of important emblems of the US political and educational scenario like the CIA, the White House and the University of California. What could be a case of legitimate political representation was, in fact, a demagogical maneuver: the appointment of Hispanic names in strategic positions within the governmental structure was just to give the impression (a false one) of genuine political engagement on the part of a minority group. As Acuña concludes, "[i]t became evident by the mid-1980's that these appointees were [actually] integral to the legitimation of government policy. They were the role models that had been picked to be celebrated" (Acuña 416). In 1991, President Bush made use of the same subterfuge while nominating a black but conservative judge for the US Supreme Court. By doing so, Bush expected to obtain votes from the conservative and also the black segments of the US electorate. Both US presidents performed what Hall (2007, p. 600-601) calls "the play of identities", as they manipulated the signification of those representatives according to their political intentions.

Perhaps due to this mood of disappointment of the 1980's that Denise Chávez made the narrator/ character in Face of an Angel enroll in a course on 
Chicano culture, whose program History was included in. It is interesting to examine the titles of three of the disciplines that compose the syllabus of the course Soveida attended: "Amnesty-Stigma or Stigmata: the Whys and Wherefores of Immigration-Who Are We Trying to Suppress?"; "La Frontera-The Tortilla Curtain-A Means of Sustenance-For Whom?"; "Las Maquiladoras-Twin-Plant Mania, Another Taiwan for the US?" (282-283-our emphasis). It is flagrant that the three titles quoted here bear a skeptical/inquisitive overtone, indicating that the course chosen by Soveida is going to follow an alternative and questioning stance, opposed to the official historical discourse. Another detail about the titles is that the three of them focus on issues that have been affecting Hispanics: immigration, the geographical boundaries between Mexico and the US and the political implications the issue involves, and the branches of multinational industries installed in Mexico with the purpose of profiting from cheap labor.

Regarding the 1980's panorama, what must be observed is that Face of an Angel was written by a Chicana, whose narrator/protagonist's intellectual blooming takes place in a period that witnesses "a virtual explosion of Latina writing" (Ortega; Sterbach in Horno-Delgado 10). Theorists and professors Eliana Ortega and Nancy Saporta Sternbach establish a causeeffect relationship between politically obscure times and creative production. As Ortega and Sternbach argue, in an era of "political repression and conservatism" (Ortega; Sternbach in Horno-Delgado 10), the flow of cultural production is interrupted and, consequently, all the country's cultural framework gets fissured. It is just the gaps left by political oppression that will be filled in by minority groups who present alternative versions of history, as the authors themselves assert:

[...] Latina writers also found a space within the fractures of the political climate of United States culture of the eighties, when many social programs disappeared, when the radicalism of the sixties movements had been co-opted, and when the dominant Anglo-American culture was empowered more than through Reaganism. (Ortega; Sternbach in Horno-Delgado 10)
While discussing this very factor, Oliver-Rotger refers to US scholars Sarah Ruddick, Mary Ryan and Nancy Fraser:

\begin{abstract}
[They] focused on the way in which marginal groups that [were] not part of the public arena [had been] "rethinking the public sphere" (Fraser 70); [t]his sphere, encompassing the apparatuses of the state, the official economy, and other forums of public opinion and discourse is generally viewed as opposed to the home, the ethnic group, sexuality, and religion, which constitute the "private" sphere of life. (Oliver-Rotger 131)
\end{abstract}

What must be taken into consideration is that most Latina writers-including Denise Chávez-were born in the 1940's and educated in 1960's, when minorities started having access to higher education. It was these women of Latin American background and with a considerable academic knowledge that "situated themselves between the cracks of the operative literary systems" (Ortega; Sternbach in Horno-Delgado 11). Soveida Dosamantes, although a fictional character, seems to fit the profile of a Latina writer outlined by Ortega and Sternbach. Besides being the fictional author of the life writing embodied in Face of an Angel, Soveida also writes the aforementioned "Book of Service", the manual she writes on how to be a good waitress. Soveida Dosamantes can be thus regarded as a fictional Latina writer whose narrative impulse was a result of the knowledge she acquired in the "Rambo years". It was exactly in the 1980's that Latina writers were mature enough to develop their own literary discourse used as their crucial tool to construct their own identity. It thus seems accurate to affirm that in a period marked by so many armed conflicts-Soviet-Afghan War, Iran-Iraq War, Lebanon War, just to mention some-the 1980's were the time when Chicano history was rewritten through the lens of women such as Sandra Cisneros, Ana Castillo, Helena Maria Viramontes and Denise Chávez, who created, in Face of an Angel, a narrator/protagonist who seems to be somehow an extension of her "self".

Other chapters included in the second half of the novel also allude to the historical panorama previously described. In the thirty-seventh chapter, entitled "The 
Night of the Cucas", during a phone conversation with her boss Larry Larragoite, Soveida mentions that "[that night] [was] the first night of [her] class" (279). Although not chronologically situated, that passage was the first reference to the course on Chicano culture already talked about. Soveida's moment of cultural awareness is temporally located chapters later, when she interviews her family's lifetime maid Oralia. That interview, which aims at collecting data for Soveida's final paper, takes place in April, 1988 (306). Therefore, it seems that Soveida's interest in acquiring literacy on her own cultural background might have been a late result of a political attitude adopted by Cesar Chávezalready talked about in this paper-back in the 1960's. That ideological posture, called si se puede, which literally means in English, "[yes], it is possible", may be interpreted as a "green light" to any progressive impetus on the part of Chicano community. Although Cesar Chavez's position had as its goal stimulating Chicanos to seek social mobility, Denise Chávez's protagonist did not have social status upward improvement as her motivation towards acquiring academic learning. Soveida actually raised the si se puede banner for selfknowledge purposes, as she focused on acquiring conscious understanding of a past she sensed she had. After all, as Rodolfo Acuña appropriately observes, "Chicano studies had [always] been a progressive force in mounting a counterhegemonic force and keeping a Chicano agenda alive" (Acuña 402).

Based on the theoretical support used to develop the present essay, it seems appropriate to conclude that Denise Chávez's Face of an Angel constitutes a novel in which the author uses historical elements to contextualise her narrator/protagonist's narrative. However, it is not the author's goal to discuss in depth any historical aspect. What seems to have been Chávez's purpose in spicing her novel with history is that of reminding her readers of Chicanos' historical conditions in a diachronic view. The author's main concern seems to have been developing an informative text, without being necessarily pedagogical; on the contrary, Chávez subtly sprinkles historical incidents in her novel, making them function as an external locator of her literary work. Thinking of postmodernity, it is not possible to consider a fictional piece of writing disconnected from the historical moment in which it was conceived. As Linda Hutcheon (1998) points out, both history and literature belong to the same cultural system and none of them is hierarchically privileged, both concurring to apply internal and external meaning to the real and the fictional worlds. After a close reading of the novel, it is visible that history and literature intertwine to form the fabric that functions as the backcloth to the scenario of sectarianism Soveida Dosamantes describes in her account.

Throughout this paper, Face of an Angel was classified as a "post/neocolonial"/"postmodern" novel. If, on the one hand, Denise Chávez developed a first person narrative, whose narrator depicts an ethos marked by ethnic miscegenation and the social discrimination it provokes, the label "post/neocolonial" seems to fit such literary work. The double prefix of the adjective points to the two instances of political and economic domination: the colonial exploitative relation to Spain that spanned from the sixteenth to the nineteenth centuries, and the not less exploitative dependence on the United States in imperialistic times, which started in the nineteenth century and continues up to now. The dislocation suffered by the characters in Chávez's novel is not caused by Spain, Mexico's European metropolis back in the Age of Discovery, but by its then new economic predator, the United States, whose economic dependence was sacred by the Treaty of Guadalupe Hidalgo in the middle of the nineteenth century. Since post-colonialism refers to the literary and critical writings produced by ex-colonies of Europe, it must be understood here that, although Mexico fits in the category, the realm created by Denise Chávez in Face of an Angel is composed by "sites and peoples involved in imperial/colonial encounters" (Encyclopedia of Canadian Writing 897-our emphasis). On the other hand, if the author composes a kaleidoscope made up of the intermix of pieces of history and artistic creation whose limits are many times difficult to identify, it seems adequate to attribute to Chávez's novel the quality of "postmodern"-the narrator/protagonist's ancestors transit in the aftermath of "The Invasion" and Ivan Torres's commenting on the campesinos' struggle are 
good examples of this kaleidoscope. Besides, Face of an Angel also deserves the label of "postmodern" as it is told by a woman who, for not holding an important social position, would not have the right to tell her own story.

In Denise Chávez's novel, the smeared frontier between factum and fictum is textually constructed by an ordinary American woman of Mexican background. Therefore, it is a common waitress from a small villageas fictional as herself-in New Mexico that takes over the chore of telling her own story, the job of giving her testimony of what she experienced either by living or by learning up to the moment of enunciation. After all, "[p]ostmodern fictions often emphasize the socially marginal ("ex-centric") person over the mainstream figure, and explore (or invent) unofficial histories as alternatives to sanctioned history" (Encyclopedia of Canadian Writing 896). Concerning the historical approach adopted, what is important to observe is that the periods picked out as references, despite being so chronologically apart, have in common a significant feature: the dislocation of the postcolonial-or neocolonial, as Ella Shohat (1992) questions-subject, who straddles between two cultures, to employ the words by Gloria Anzaldúa (1999). This amalgam of history and fiction forms a cut-out of a singular world that bears a set of particularities, a world which minorities must reconstruct in order to represent themselves.

\section{Notes}

1. Denise Chávez (1948) is a Mexican-American writer who represents in her literary work the ethos she grew up in. Practically unknown in Brazil, she was 1995 The American Book Award winner for Face of an Angel.

2. From here on all references to the novel will be made by the page number only.

3. "engage in the buying or selling of a commodity with an element of risk on the chance of profit" (available at http://www.answers.com/topic/speculate > Access in September, 2013.

4. Ideology developed in the mid 1840 s considered an aftermath of the Monroe Doctrine. Alleging the superiority of the Anglo-Saxon race, it justified the U.S expansion into Latin American countries. (OliverRotger, 2003, p. 99).

5. Including Mexican-Americans in this group.
6. https://www.goodreads.com/book/show/130440. Doctor_Zhivago - access in October, 2013.

7. Director of the National Council of La Raza-In: ACUÑA, 1988, p. 413.

\section{Works Cited}

Acuña, Rodolfo. Occupied America: a History of Chicanos. New York: Harper Collins Publishers, $3^{\text {rd }}$ ed., 1988. Print.

Anzaldúa, Gloria. Borderlands the New Mestiza-La Frontera. San Francisco: Aunt Lute Brooks, 1999. Print.

Anderson, Benedict. Imagined Communities. New York: Verso, 1991. Print.

Blake, Debbie et al. An Interview with Denise Chávez. Web July $2003<\mathrm{http}$ //ir.uiowa.edu/cgi/viewcontent.cgi?art icle $=1161 \&$ context $=i j c s>$.

Chávez, Denise. Face of an Angel. New York: Warner Books, 1994. Print.

Glissant, Edouard. Caribbean Discourse-selected essays. Chalottesville: University Press of Virginia, 1992. Print.

Hall, Stuart, et al. Modernity: an Introduction to Modern Societies. Oxford: Blackwell Publishing, 2007. Print.

Horno-Delgado, Asunción, et al. Breaking Boundaries: Latina Writing and Critical Readings. Amherst: The University of Massachusetts Press, 1989. Print.

Hutcheon, Linda. A Poetics of Postmodernism. London: Routledge, 1988. 105-123. Print.

Historiographic Metafiction-Parody and the Intertextuality of History. 1989. Web March, 2012. <ieas.unideb.hu/admin/file_3553.pdf>.

Korhonen, Kuisma (ed.). Tropes for the Past-Hayden White and the History/Literature Debate. New York: Rodopi, 2006. 9-20. Print.

McCracken. Ellen. New Latina Narrative: The Feminine Space of Postmodern Ethnicity. Tucson: The University of Arizona Press. 1999. Print.

"Postcolonialism." Encyclopedia of Canadian Writing. Toronto: University of Toronto Press, 2002 Print.

Oliver-Rotger, Maria Antonia. Battlegrounds and Crossroads-Social and Imaginary Space in Writings by Chicanas. New York: Rodopi, 2003. Print.

Radstone, Susannah. Autobiographical Times. In: Cosslett, Tess (et.al.). Feminism and Autobiography: Texts, Theories, Methods. London: Routledge, 2000. 201-219. Print. 
Richter, Francine. "Romantic Women and La LuchaDenise Chávez's Face of an Angel". University of Nebraska-Lincoln. 1999. Web December, 2012. <http:// digitalcommons.unl.edu/greatplainsquarterly/907>.

Shohat, Ella. "Notes on the Post-Colonial". In: Social Text, number 31/32, Third World and Post-Colonial Issues, 1992, p. 99-113. Web July 2013 <http://www.jstor.org/ stable/466220>.

White, Hayden. Historical Discourse and Literary Writing. IN: Korhonen, Kuisma (ed.). Tropes for the Past-Hayden White and the History/Literature Debate. Amsterdam-New York: Rodopi, 2006. 25-33. Print.

Recebido em: 29/07/2014

Aceito em: 01/09/2014 
